\title{
SKEPTISME PROFESIONAL ANTACEDENT PERILAKU PREMATURE SIGN OFF AUDITOR
}

\author{
PROFESSIONAL SKEPTICISM ANTACEDENT OF PREMATURE SIGN OFF \\ AUDITOR \\ Oleh: \\ Nanik Sri Utaminingsih \\ Universitas Negeri Semarang \\ nie.pasadena@gmail.com
}

\begin{abstract}
Abstrak
Penelitian ini bertujuan untuk mengetahui faktor-faktor yang mempengaruhi perilaku premature sign off pada auditor di wilayah kota Semarang. Orisinalitas yang disajikan dalam penelitian ini, adalah penggunaan tingkat skeptisme profesional auditor, sebagai variabel prediktor pada premature sign off auditor. Justifikasi penggunaan variabel ini didasarkan pada pendekatan Tripartite Nature of Auditors' Attitude of Profesional Skepticism.

Penelitian ini menggunakan metode survey yang melibatkan auditor eksternal di kota Semarang. Teknik pengumpulan data melalui penyebaran instrumen kuesioner. Hasil penelitian menunjukkan bahwa time budget pressure, kontrol kualitas serta skeptisme profesional auditor memiliki pengaruh terhadap tindakan premature sign off.
\end{abstract}

Kata Kunci: Premature sign off, time budget pressure, kontrol kualitas, skeptisme profesional.

\begin{abstract}
This research aims to determine the factors that affect premature sign off on an auditor in the city of Semarang. Originality presented in this study, is the use of the auditor's professional skepticism level, as a predictor variable in premature sign off auditors. Justifying the use of these variables is based on the approach Tripartite Nature of Auditors' Attitude of Professional Skepticism.

This study used survey method involving the external auditor in the city of Semarang. Data collection through a questionnaire instrument deployment. The results showed that the time budget pressure, quality control as well as the auditor's professional skepticism has an influence on the actions premature sign off.
\end{abstract}

Keywords: Premature sign off, time budget pressure, quality control, professional skepticism

\section{PENDAHULUAN}

Perilaku premature sign off pada diri auditor merupakan salah satu bentuk dari perilaku disfungsional. Perilaku yang menyimpang ini, akan berakibat pada rendahnya kualitas audit. Hal ini bertentangan dengan tujuan dilakukannya audit. Arens et al (2011) mendefinisikan bahwa assurance service sebagai: "independent professional service that improve the quality of information, for decision maker". Artinya kualitas audit merupakan salah satu pertimbangan yang sangat dibutuhkan dalam pembuatan keputusan klien.

Untuk menjaga kualitas audit, maka standar auditing digunakan sebagai pedoman pelaksanaan audit. Akan tetapi, fenomena yang berkembang dalam dunia praktek auditor, menunjukkan masih terdapat berbagai pengurangan kualitas audit (reduced audit quality). Berbagai skandal keuangan seperti Lehman Broters, Olympus Corporationa dsb merupakan hasil adanya 
manipulasi laporan keuangan, yang lepas dari pengamatan auditor. Data yang diperoleh dari laporan Association of Certified Fraud Examiners, Kecurangan secara menyeluruh terdeteksi oleh external audit di tahun 2010 sebesar 4,6 \% dan ditahun 2012 sebersar 3,3\%. Angka di atas menunjukkan bahwa telah terjadi peningkatan kerugian dan penurunan prosentasi kecurangan yang terdeteksi.

Boyle \& Carpenter (2015) menyatakan kualitas audit dapat ditingkatkan, melalui praktek KAP, budaya dan remediation terhadap nilai-nilai independesi, obyektifitas dan professional skeptisme. Sementara Gerald Kasigwa (2013) menyatakan rendahnya kualitas audit merupakan akibat adanya reduce audit quality behavior (RAQ). Charles \& Robin (1996) menyatakan bahwa bentuk tindakan pengurangan kualitas audit,merupakan bentuk penyimpangan. Bentuk penyimpangan yang sering dilakukan adalah premature signing-off audit dan underreporting.

Berbagai riset terkait pemotongan prosedure audit atau premature sign off (PSO), menunjukkan bahwa terdapat faktorfaktor antacendent, yang dapat memicu seorang auditor untuk melakukan tindakan tersebut. Mendasarkan pada teori pengambilan keputusan dengan pendekatan Interaction Model of Ethical desicion making in organizations. Pendekatan ini dikembangkan oleh Trevino (1986), dan digunakan untuk menjelaskan bahwa tindakan PSO, sebagai tindakan tidak etis, merupakan hasil interkasi antara komponen individual dan komponen situasional. Individual moderator, merupakan kekuatan yang berasal dari diri auditor, dapat berupa kekuatan ego, locus of controll, kompentensi dan sebagainya. Sedangkan situasional moderator, dapat berupa tekanan yang diperoleh dari luar diri auditor, dapat berupa budaya organisasi, tekanan organisasi. Kedua faktor moderasi tersebut berinteraksi dengan tingkat kognitive yang dimiliki auditor, menghasilkan keputusan etis atau tidak etis.

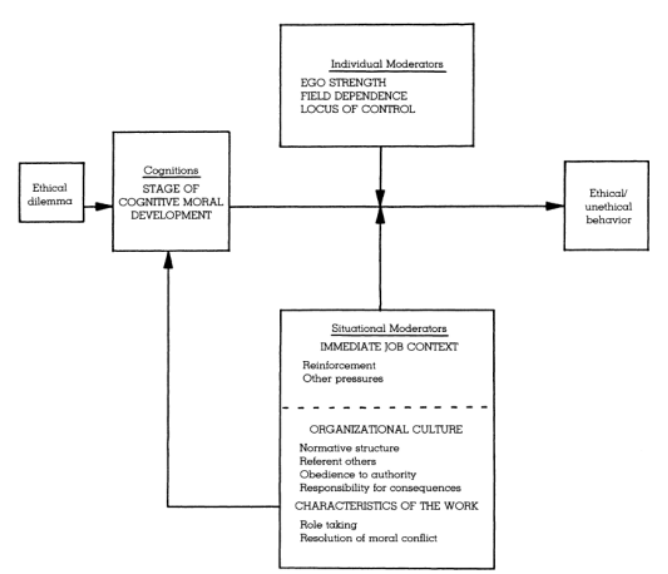

\section{Gambar 1. Interaction Model of Ethical desicion making in organizations}

Sumber : Trevino (1986)

Riset terkait tindakan PSO telah banyak dilakukan yang menghasilkan berbagai faktor antasenden, misalnya komitmen organisasi, budaya, locus of controll, time budget pressure, komitmen profesi dan berbagai faktor antasenden yang lain. (Tabatabaei \& Hoseinzadeh.2016; Barrainkua \& Pike. 2015; Svanström. 2015; Svanberg \& Öhman. 2016; Sari Ratna, Tenriwaru. 2016; Smith \& Ismail. 2012; Paino, Ismail, \& Smith. 2011; Otley \& Pierce. 1996. Malone \& Roberts. 1996; Coram, Ng, \& Woodliff. 2003; Charles \& Robin. 1996). Akan tetapi peneliti menduga terdapat determinan yang memiliki kontribusi yang besar terhadap tindakan PSO pada auditor. Pertimbangan ini didasarkan pada pendekatan judgment decision making bahwa profesionalisme memiliki kontribusi terhadap judgment yang dihasilkan auditor. Lebih lanjut Standar auditing menetapkan bahwa profesionalisme yang dimaksud adalah sikap skeptisme profesional. Pernyataan ini didukung riset Boyle \& Carpenter ( 2015) bahwa kualitas audit dapat ditingkatkan melalui peningkatan kualitas skeptisme profesional.

Standard profesional akuntan publik mendefinisikan skeptisisme profesional sebagai sikap auditor yang mencakup pikiran yang selalu mempertanyakan dan melakukan evaluasi secara kritis terhadap bukti audit. Berbagai riset terkait skeptisme 
profesional menunjukkan bahwa sikap skeptisme merupakan hasil dari proses kognitif, sedangkan proses kognitif dipengaruhi oleh berbagai faktor input yang berupa karakteristik auditor, karakteristik klien, karakteristik bukti dan karakteristik lingkungan (Nolder \& Kadous, 2014). Skeptisme profesional merupakan konstruk yang memiliki sifat continuum, artinya tingkat skeptisme yang dimiliki auditor saat melakukan penugasan merupakan gradasi yang sesuai dengan fator potensial yang ada dalam situasi yang dihadapinya. Saat auditor berhadapan dengan situasi klien yang memiliki tingkat kecurigaan mengalami fraud yang tinggi, maka seharusnya auditor lebih bersikap skeptisme dibandingkan jika berada dalam situasi klien yang tidak mengalami fraud.

Pada saat skeptisme auditor ditetapkan dalam tingkat yang cenderung tinggi, maka auditor sewajarnya mengambil sikap untuk menghindari tindakan PSO. Hal ini sesuai dengan pendekatan Tripartite Nature of Auditors' Attitude of Professional Skepticism, yang menjelaskan bahwa skeptisme profesional dapat dipandang sebagai sebuah sikap yang merupakan hasil dari cognitions, affections dan conations. Di mana cognitions menjelaskan bahwa skeptisme merupakan hasil kognitif yang berdasarkan pada belief. Affections menjelaskan bahwa skeptisme yang merupakan perasaan yang muncul untuk merespon resiko salah saji dan kesalahan terhadap ketidakcukupan bukti, serta conations yang menjelaskan intensitas dan tindakan auditor untuk melakukan perluasan dan kapan prosedur audit dilakukan ataupun sebalikya.

Riset yang menggunakan skeptisme profesional sebagai faktor antasedent terhadap tindakan PSO, sejauh ini belum dilaksanakan, sehingga belum diketahui bagaimana hubungan tindakan skeptisme terhadap PSO. Pertimbangan rasional yang bisa diperoleh dari Tripartite Nature of Auditors' Attitude of Profesional Skepticism.

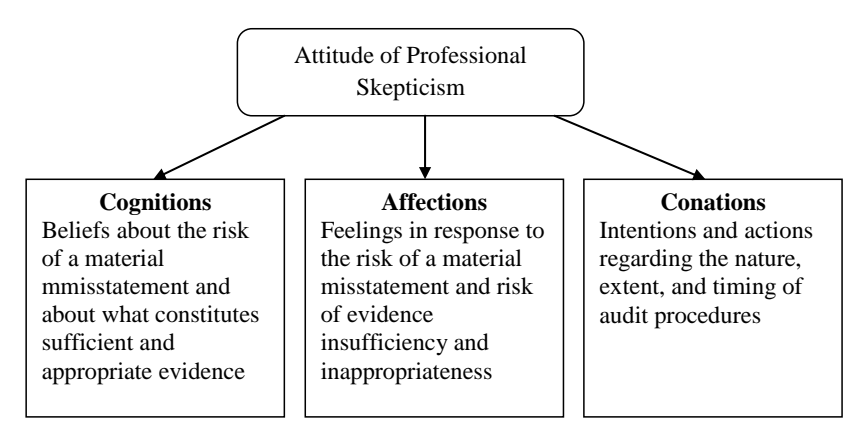

Gambar 2. Tripartite Nature of Auditors' Attitude of Profesional Skepticism.

Sumber: Nolder \& Kadous (2014)

Pendekatan di atas menunjukkan bahwa pada komponen conations, auditor memiliki kecenderungan bertindak dengan mendasarkan judgment untuk memperluas prosedur audit atau justru sebaliknya. Alur model Tripartite di atas, seiring dengan model pengambilan keputusan etis, yang dikembangkan oleh Trevino. Sehingga peneliti menduga bahwa tindakan PSO di pengaruhi oleh tingkat skeptisme profesional auditor. Dan dirumuskan dalam hipotesa sebagai berikut:

Ha1 = Terdapat pengaruh signifikan atas skeptisme profesional terhadap tindakan PSO auditor.

Untuk melihat pengaruh skeptisme terhadap PSO, peneliti menambah variabel yang mempengaruhi PSO, yaitu time bdget pressure (TBP) serta kontrol kualitas, yang merupakan faktor situasional. Riset terkait pengaruh time pressure terhadap PSO, telah dilakukan oleh Coram, $\mathrm{Ng}$, \& Woodliff (2003) menemukan hasil bahwa time budget pressure berhubungan terhadap tindakan RAQ. Gundry \& Liyanarachchi, (2007) menemukan time budget pressure tidak berpengaruh terhadap RAQ, khususnya pada tindakan weak client explanation. Svanberg \& Öhman (2013) menguji dampak budaya etika dan time budget pressure memberikan hasil bahwa time budget pressure tidak berpengaruh terhadap tindakan RAQ. Svanström (2015) menguji hubungan antara time pressure, aktivitas pelatihan dan perilaku disfungsional auditor pada KAP kecil menunjukkan hasil TBP berhubungan positif. Riset-riset di atas menunjukkan 
bahwa pengaruh TBP terhadap RAQ masih menunjukkan hasil yang belum konsisten, sehingga masih perlu dilakukan pengujian ulang, bagaimana pengaruh TBP terhadap tindakan RAQ. Berdasarkan pemikiran di atas, maka dirumuskan hipotesa sebagai berikut:

Ha2: Terdapat pengaruh time budget pressure terhadap tindakan premature sign off audit

Kontrol kualitas lebih berfokus pada pelaksanaan prosedur audit sesuai standar auditing. Pelaksanaan kontrol kualitas yang baik akan meningkatkan kemungkinan terdeteksinya perilaku auditor yang menyimpang, seperti praktik penghentian prematur atas prosedur audit. Kemudahan pendeteksian ini akan membuat auditor berpikir dua kali ketika akan melakukan tindakan semacam penghentian prematur atas prosedur audit. Semakin tinggi kemungkinan terdeteksinya praktik penghentian prematur atas prosedur audit melalui kontrol kualitas, maka semakin rendah kemungkinan auditor melakukan praktik tersebut. Sehingga kontrol kualitas mempunyai hubungan negatif terhadap premature sign off. Sehingga dirumuskan hipotesa sebagai berikut:

Ha3: Terdapat pengaruh kontrol kualitas terhadap tindakan premature sign off audit

\section{METODE PENELITIAN Jenis Penelitian}

Penelitian ini merupakan penelitian survey. Populasi penelitian adalah auditor yang bekerja pada KAP di wilayah kota Semarang. Data yang digunakan adalah data cross section yaitu data yang dikumpulkan dalam periode tertentu, yaitu di bulan November tahun 2016. Jumlah kuesioner yang dikirim sejumlah 100 kuesioner.

Untuk menghindari rendahnya respon rate, maka peneliti melakukan organizational contac, dengan melakukan kontak person, untuk mengetahui waktu yang tepat untuk menerima survey dan memberikan alternatif cara penerimaan survey. Jumlah responden yang mengembalikan kuesioner sebanyak 78 responden, dari $10 \mathrm{KAP}$ yang bersedia untuk mengisi.

Test non respon bias, dilakukan dengan membandingkan antara kuesioner yang kembali di awal dan instrumen yang kembali di akhir masa pengumpulan (sebagai proksi bagi auditor yang tidak menjawab). Hasil uji beda menunjukkan tidak terdapat perbedaan respon antara yang menjawab dengan tidak menjawab.

Dalam penelitian ini premature $P S O$ didefiniskan sebagai penghentian prematur atas prosedur audit merupakan penghentian satu atau beberapa langkah audit yang diperlukan dalam prosedur audit tanpa diganti dengan prosedur yang lain, namun auditor berani memberikan opini atas suatu laporan keuangan.(Shapeero, Koh, \& Killough, 1988)

Indikator-indikator yang digunakan dalam penelitian ini mengenai premature sign off adalah:

1. Pengujian Analitik

2. Pengujian pengendalian

3. Pengujian subtantif

Time pressure merupakan suatu kondisi dimana auditor dituntut dari tempat bekerja untuk melakukan efisiensi biaya dan waktu dalam melaksanakan audit sesuai dengan waktu yang telah ditetapkan. (Svanberg \& Öhman, 2013)

Indikator-indikator dalam time pressure ini adalah:

\section{Time budget pressure}

2. Time deadline pressure

Kontrol kualitas lebih berfokus pada pelaksanaan prosedur audit sesuai dengan standart auditing ataukah tidak. Hal ini dilakukan sebagai usaha untuk menekan angka kecurangan yang dilakukan oleh auditor.(Svanberg \& Öhman, 2013)

Indikator-indikator dalam kontrol kualitas adalah:

1. Integritas dan objektivitas

2. Monitoring

Skeptisme profesional menggunakan instrument Hurtt (2010) dengan menggunakan 6 kriteria yaitu: 


\section{Questioning Mind}

Sikap selalu mempertanyakan adalah karakteristik pertama yang menjadi indikator untuk mengetahui tingkat skeptisme profesional auditor.

2. Suspension of judgment

Kriteria kedua ini mengacu pada konsep bahwa judgmen auditor seharusnya memiliki sifat kecurigaan hingga auditor mampu mengumpulkan bukti yang cukup.

3. Search for knowledge

keinginantahuan atau ketertarikan. Sikap ingin tahu, pada dasarnya akan mampu menstimulasi seseorang untuk meningkatkan rasa ketertarikan, dan juga memicu seseorang untuk berusaha mengeksploitasi dan berusaha menemukan hal-hal baru untuk meningkatkan pemahamannya.

4. Interpersonal understanding

Auditor dalam mengevaluasi bahan bukti, auditor harus memahami, bagaimana motivasi dan persepsi penyedia bahan bukti.

5. Self-esteem

Self-esteem adalah karakteristik yang berupa perasaan terhadap kekuatan diri dan keyakinan terhadap kemampuan diri sendiri.

\section{Autonomy}

Autonomy merupakan pertimbangan bahwa bukti audit yang dikumpulkan telah memenuhi kecukupan untuk digunakan sebagai landasan pengambilan judgment

\section{Teknik Analisis Data}

Analisis data menggunakan regressi berganda, untuk mengetahui hubungan dan pengaruh variabel independen terhadap variabel dependen, dengan menggunakan alat bantu SPSS 20. Uji kualitas data dan normalitas telah dilakukan dan hasillnya menunjukkan model regressi layak untuk dilanjutkan.

\section{HASIL PENELITIAN DAN PEMBA- HASAN}

Hasil penelitian terhadap perilaku PSO pada auditor di wilayah kota Semarang menunjukkan bahwa rata-rata perilaku PSO auditor sebesar 12,85. Tabel 1 . menunjukkan tingkat minimum 7 dan maksimum 35, semakin kecil nilai total PSO menunjukkan auditor semakin sedikit melakukan pemotongan prosedur.Hasil mean PSO menunjukkan nilai 12,85 bahwa secara rata-rata auditor di kota Semarang cenderung melakukan PSO, walaupun tidak pada semua prosedur.

\begin{tabular}{|c|c|c|c|c|}
\hline & $\mathbf{N}$ & Minimum & Maximum & Mean \\
\hline TPSO & 78 & 7 & 35 & 1285897436 \\
\hline TBP & 78 & 5 & 23 & 14.25641026 \\
\hline TKK & 78 & 11 & 18 & 14.56410256 \\
\hline TSP & 78 & 83 & 120 & 109.2435897 \\
\hline Valid N (listwise) & 78 & & & \\
\hline
\end{tabular}

Sedangkan untuk skeptisme profesional (Total Skeptisme profesional/TSP) menunjukkan nilai mean sebesar 109,24, dengan nilai maksimum sebesar 120. Ini menunjukkan sebagian besar auditor di Semarang menunjukkan memiliki skeptisme profesional yang cenderung tinggi.

Tabel 2. Menunjukkan nilai korelasi antara variabel independen terhadap variabel dependen.

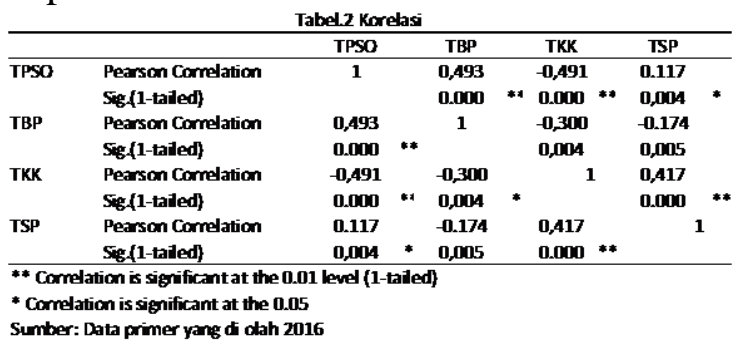

Hasil korelasi menunjukkan TBP, TKK serta TSP memiliki korelasi yang signifikan terhadap tindakan premature sign off.

Tabel 3 menunjukkan hasil pengujian regressi terhadap ketiga variabel independen terhadap variabel dependen.

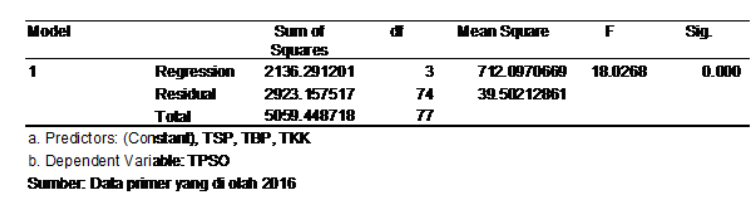

Secara simultan variabel independen yang terdiri dari time budget pressure, kontrol kualitas serta skeptisme profesional 
berpengaruh terhadap tindakan premature sign off audit. Sedangkan pengaruh parsial di tunjukkan dalam tabel 4.

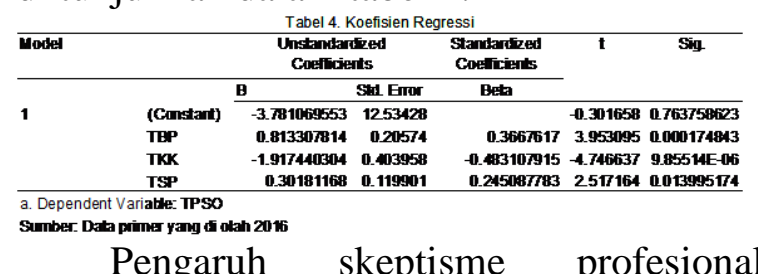

Pengaruh skeptisme profesional terhadap perilaku PSO dapat diketahui dengan menggunakan nilai probabilitas. Hasil pengujian menunjukkan nilai signifikasi sebesar 0,013. Nilai ini di bawah 0,05 sehingga dapat disimpulkan bahwa skeptisme profesional berpengaruh terhadap PSO, sehingga Hal dapat diterima. Saat seorang auditor memiliki skeptisme yang tinggi, maka sikap mempertanyakan, keinginantahuan, sikap percaya diri, sikap memiliki autonomy, memberikan pengaruh atas keputusannya untuk tidak memotong prosedur audit yang seharusnya dilakukannya. Hal ini sesuai dengan Tripartite Nature of Auditors' Attitude of Profesional Skepticism, bahwa secara konation, auditor akan bereaksi untuk memperluas prosedur auditnya atau sebaliknya sebagai respon terhadap belief dan feeling yang dimilikinya saat berhadapan dengan resiko salah saji yang terdapat dalam laporan keuangan klien.

Pengaruh TBP terhadap TPSO ditunjukkan pada nilai signifikasi sebesar 0,000 artinya TBP secara signifikan berpengaruh parsial terhadap TPSO, sehingga $\mathrm{Ha} 2$ diterima. Hal ini sesuai dengan riset Coram et al ( 2003), Yuen, Law, Lu, \& Guan, (2013), Gundry \& Liyanarachchi ( 2007), (Sari Ratna, Tenriwaru ( 2016). Time budget pressure atau tekanan atas budget waktu di alami oleh auditor, maka seorang auditor akan melakukan rasionalisasi terhadap prosedur audit yang dilakukannya. Walaupun beberapa riset mengemukakan, bahwa tekanan waktu yang dialami auditor, di lain pihak akan memberikan stimulus untuk meningkatkan produktivitas auditor, akan tetapi pada titik tertentu, maka tekanan waktu dapat berubah sebagai faktor antasenden yang dapat mempengaruhi auditor untuk melakukan pemotongan prosedur audit.

Pengaruh kontrol kualitas terhadap tindakan premature sign off ditunjukkan pada tabel 4, dengan nilai signifikasi sebesar 0,000. Sehingga hipotesa Ha3 diterima, terdapat pengaruh kontrol kualitas terhadap tindakan PSO. Hasil ini sesuai dengan riset yang telah dilakukan oleh Otley \& Pierce (1996b) bahwa saat sebuah KAP melakukan kontrol kualitas yang lebih ketat, maka akan mengurangi tindakan premature sign off.

Sebagai tambahan pengujian, peneliti mencoba untuk melakuan beberapa model regressi sebagai bahan komparasi, apakah skeptisme profesional merupakan faktor antasenden yang memiliki kontribusi yang besar terhadap tindakan premature sign off. Tabel 5, menyajikan komparasi model.

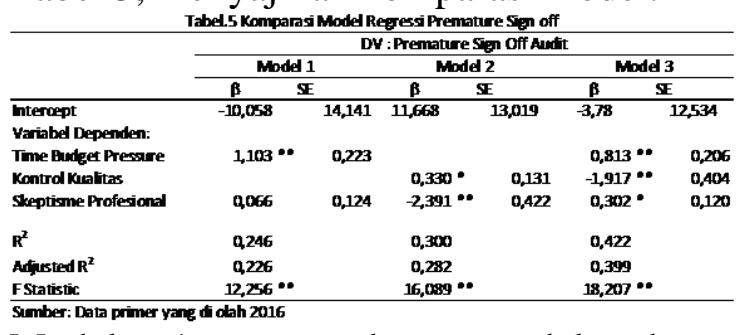

Model 1 merupakan model dengan menggunakan variabel independen berupa TBP dan TSP, hasil pengujian menunjukkan secara keseluruhan kedua variabel tersebut menunjukkan pengaruh. Akan tetapi pengaruh parsial, hanya TBP yang memiliki pengaruh signifikan terhadap PSO sebesar 1,103. Sedangkan skeptisme profesional tidak berpengaruh terhadap PSO secara parsial. Nilai $\mathrm{R}^{2}$ pada model 1 sebesar 0,246 relatif lebih kecil dibanding model 2 dan 3 .

Untuk model 2, variabel prediktor yang digunakan meliputi kontrol kualitas dan skeptisme profesional. Secara simultan, menunjukkan keduanya memiliki pengaruh yang signifikan terhadap PSO, dengan nilai F statistik 16,089 signifikan pada tingkat 0,01 . Secara parsial kedua variabel prediktor memiliki pengaruh yang signifikan. Kontrol kualitas memiliki koefisien 0,330 signifikan pada tingkat 0,05 . Sedangkan skeptisme profesional memiliki koefisien -2,391 signifikan pada tingkat 0,01 . Nilai koefisien 
skeptisme profesional menunjukkan berhubungan negatif terhadap premature sign off. Nilai $\mathrm{R}^{2}$ menunjukkan 0,30 ini menunjukkan bahwa variabel PSO dapat dijelaskan oleh variabel prediktor sebesar $30 \%$.

Model 3 menggunakan 3 variabel prediktor, yaitu time budget pressure, kontrol kualitas, dan skeptisme profesional. Hasil pengujian menunjukkan nilai $\mathrm{R}^{2}$ sebesar 0,422 dengan nilai $\mathrm{F}$ sebesar 18,027 , signifikan pada 0,005 . Nilai $R^{2}$ pada model ini, menunjukkan nilai yang relatif lebih besar dibanding 2 model sebelumnya. Pengaruh secara parsial variabel time budget pressure terhadap PSO memiliki koefisien 0,813 signifikan pada 0,01 . Sedangkan kontrol kualitas memiliki nilai koefisien -1.917 signifikan pada 0,001 serta skeptisme profesional memiliki koefisien sebesar 0,302 signifikan pada 0,05 .

Hasil komparasi pada ketiga model menunjukkan adanya perbedaan koefisien pada variabel skeptisme profesional. Model 1 dan 3 memberikan arah yang positif terhadap hubungan pengaruh skeptisme profesional terhadap PSO. Sedangkan model 2 memberikan arah yang negatif terhadap pengaruh skeptisme terhadap PSO. Hal ini, memberikan makna, bahwa pengujian atas pengaruh skeptisme profesional terhadap premature sign off perlu ditindaklanjuti oleh peneliti berikutnya.

\section{Saran}

Penelitian ini merupakan penelitian yang memiliki orisinalitas dengan memasukkan variabel skeptisme profesional sebagai variabel prediktor terhadap tindakan premature sign off, sehingga sangat dimungkinkan riset selanjutnya dapat menguji ulang variabel skeptisme profesional, dengan menambah sampel atau menempatkan variabel skeptisme sebagai variabel moderating ataupun intervening dengan mendasarkan pada pertimbangan metodologi.

Pengujian terhadap pengaruh skeptisme terhadap PSO, juga dapat dilakukan dengan menambahkan variabel yang berasal dari faktor individual moderator ataupun situasional moderator, sebagaimana disarankan pada pendekatan Interaction Model of Ethical desicion making in organization.

Penelitian skeptisme profesional terhadap PSO, juga dapat dikembangkan melalui jenis penelitian lain, misalnya eksperimen.

\section{DAFTAR PUSTAKA}

Barrainkua, I., \& Pike, M. (2015). New Insights into underreporting of time: The audit partner context. Accounting, Auditing \& Accountability Journal, 28(4), 494-514.

Boyle, B. D. M., \& Carpenter, B. W. (2015). Demonstrating Skepticism. The CPA Journal, (March), 31-36.

Charles, F., \& Robin, W. (1996). Factors associated with the incidence of reduced audit quality behaviors. Auditing: A Journal of Practice \& Theory, 15(2).

Coram, P., Ng, J., \& Woodliff, D. (2003). A survey of time budget pressure and reduced audit quality among Australian auditors. Australian Accounting Review, 13(1).

Gundry, L. C., \& Liyanarachchi, G. A. (2007). Time budget pressure, auditors ' personality type, and the incidence of reduced audit quality prac ... Pasicif Accounting Review, 19(2).

Hurtt, R. K. (2010). Development of a Scale to Measure Professional Skepticism. Auditing: A Journal of Practice \& Theory, 29(1), 149-171. http://doi.org/10.2308/aud.2010.29.1.1 49

Kasigwa, G., Munene, J. C., \& Nkote, I. (2013). REDUCED AUDIT QUALITY BEHAVIOR AMONG AUDITORS IN UGANDA Gerald Kasigwa Joseph Ntayi. African Journal of Accounting, 
Economic, Finance and Banking Research, 9(9), 25-38.

Malone, C. F., \& Roberts, R. W. (1996). Factors associated with the incidence of reduced audit quality behaviors. Auditing, 15(2), 49-64.

Nolder, C., \& Kadous, K. (2014). The Way Forward on Professional Skepticism: Conceptualizing Professional Skepticism as an Attitude.

Otley, D. T., \& Pierce, B. J. (1996a). Auditor time budget pressure : consequences and antecedents. Accounting, Auditing \& Accountability Journal, 9(1), 31-58.

Otley, D. T., \& Pierce, B. J. (1996b). The operation of control systems in large audit firms. Auditing: A Journal of Practice \& Theory, 15(2).

Paino, H., Ismail, Z., \& Smith, M. (2011). Dysfunctional Audit Behaviour: The Effects of Employee Performance, Turnover Intentions and Locus of Control. Dysfuungstional Audit Behavior: The Effects of Employee Performance, Turnover Intentions and Locus of Control, 7(4), 418-423.

Sari Ratna, Tenriwaru, M. A. P. (2016). Effect of time budget pressure and locus of control of auditor dysfunctional behaviors (survey ono legilative auditor bpkp gorontalo province). Jorunal of Education and Vocational Research, 7(1), 6-13.

Shapeero, M., Koh, H. C., \& Killough, L. N. (1988). Underreporting and premature sign-off in public accounting. Managerial Auditing Journal, 18(6), 478-489.

http://doi.org/10.1108/0268690031048 2623

Smith, M., \& Ismail, Z. (2012). Auditor acceptance of dysfunctional behaviour An explanatory model using individual factors. Journal of Applied Accounting Research, 13(1), 37-55. http://doi.org/10.1108/0967542121123 1907

Svanberg, J., \& Öhman, P. (2016). The effects of time budget pressure, organisational-professional conflict, and organisational commitment on dysfunctional auditor behaviour. International Journal Accounting, Auditing and Performance Evaluation, 12(2).

Svanberg, J., \& Öhman, P. O. (2013). Auditors ' time pressure: does ethical culture support audit quality? Managerial Auditing Journal, 28(7), 572-591. http://doi.org/10.1108/MAJ10-2012-0761

Svanström, T. (2015). Time Pressure , Training Activities and Dysfunctional Auditor Behaviour: Evidence from Small Audit Firms. http://doi.org/10.1111/ijau.12054

Tabatabaei, P., \& Hoseinzadeh, A. (2016). Investigate the effect of organizational commitment and professional commitment on dysfunctional behavior of auditors Introduction: International Academic Institute for Science and Technology, 3(1), 1-12.

Trevino, L. K. (1986). Ethical Decision Making in Organizations: A PersonSituation Interactionist Model, 11(3), 601-617.

Yuen, D. C. Y., Law, P. K. F., Lu, C., \& Guan, J. Q. (2013). Dysfunctional auditing behaviour: empirical evidence on auditors 'behaviour in Macau. International Journal of Accounting and Information Management, 21(3), 209-226. http://doi.org/10.1108/IJAIM-12-20120075 